\title{
Small and Large Firm Performance Gaps in Indonesia: Evidences from the 1981-2008 Indonesian Manufacturing
}

\author{
Ari Kuncoro ${ }^{\mathrm{a}, *}$ \\ ${ }^{a}$ Faculty of Economics and Business, Universitas Indonesia
}

\begin{abstract}
This study aims to examine the impacts of globalization on the performance gap between small and large firms in Indonesia, specifically in the manufacturing sector. First, the study addresses whether there are performance differentials between small and large firms, and if so, whether such gap is increasing while controlling for firm characteristics such as age, finance, export orientation, industry, and macroeconomic indicators. Second, the study discusses whether the opening of domestic market through trade and FDI liberalization affect firms disproportionately with respect to firm size. The study highlights such impacts amid successive economic reforms from 1986 to 1994. The empirical results suggest that opening the economy through market liberalization increased the productivity and wages gaps between large and small firms before it stabilized. Factors such as industrial agglomeration, financial access, export orientation have minimal impact on firms. The findings also suggest that while empirically, small firms benefit from more open trade regime after Asian financial crisis, the medium and large firms have more chance to benefit from the liberalization of the economy in general. Policy implications are also further explored.
\end{abstract}

Keywords: liberalization; small firm; large firms; manufacturing; Indonesia JEL Classification: D24; F14; F21

${ }^{*}$ Corresponding Author: FEB UI, Widjojo Nitisastro Campus, Prof. Dr. Sumitro Djojohadikusumo Str., UI Depok Campus 16424. E-mail: ari.kuncoro@ui.ac.id; arik.lpemfeui@gmail.com. 


\section{Introduction}

\subsection{Background}

Globalization is a process whereby countries become more integrated via movements of goods, capital, labor and ideas. Firms now have to compete domestically and internationally. Fast changing business environment is fact of life that has to be faced by corporations in the globalization. To survive firms need to adapt quickly with ever changing market demand. In this respect the ability to adapt would differ between different types of firms. One important observable feature that distinguishes one firm from another is its size. Our understanding on firm evolution with respect to the size has progressed a long way from the Gibrat Law which postulates that firm size is independent of its performance. To the contrary, the seminal paper by Evans (1987) found that firm size is related to its performance measured by firm growth. More recent empirical works however no longer view firm size as the sole indicator to measure performances. Instead, they employ indicators such as profitability, productivity, sales etc. The conventional wisdom at present is that although the initial size is still important, the process is more complex and is taken within the light of factors external to the firm.

One important factor considered above is access to external borrowings. Firm performances are affected by high borrowing cost and limited access to external financing. The channels through which these factors operate to affect firm performances are entrepreneur in carrying out investment and how they finance it (Fazzari et al., 1988; Hubbard, 1998). In this setting, a firm is considered as financially constrained if the cost or availability of external funds prevents a firm to exercise the level of the optimum investment which leads to suboptimal performances. Firm size is considered as an important leverage for external borrowing, the larger is the firm the better is its access to external financing (Harris et al., 1994; Bhaduri, 2005).

In other examples however, small size is often considered as an advantage (Porter, 1979; Caves and Porter, 1979; Agarwal and Audrescth, 2001). Small firms can avoid being confronted by the lower likelihood of survival by occupying a strategic niche. In Kuncoro (2006) being small is meant to avoid harassment from corrupt bureaucrats and rigid labor market.

There is a concern that in the era of globalization the gap between small and larger firms is increasing in favor of the later. For policy makers, given the different roles of small and large firms in the economy, this pose a challenge that needs to be addressed since a strong and sustained growth in East Asian economies would require a healthy gap between small and larger firms if the suspected gap does indeed exist. In the end whether larger firms perform better than the smaller firms is a matter of empirical question. The advancement of globalization while on one hand it makes the picture more complicated, in reality it does not change the facts that each type of firm - small or large - has its own survival strategy. To resolve this one needs to conduct a rigorous empirical study. 


\subsection{Research Questions}

The relationship between globalization and firm performance is a complex one. Increasing imports and inward foreign direct investment (FDI) brought by decreasing trade barrier would intensify competition in the domestic market and erode the domestic firms' profitability. This will force domestic firms to produce efficiently (Bertschek, 1995). In the long-run it may produce a healthier industry as weaker firms are eliminated through competition. On the other hand imperfection or market failure for example in the capital market may make small firms with less access to capital and information technology to fail. The results are just the opposite where the whole branch of industry dominated by small firms may disappear altogether (Braga and Wilmore, 1991). In the Indonesian context to which direction the relationship between globalization and small firm performance would turn is still unclear.

For this, the purpose of the study is to examine of the impact of globalization on the performance gap between small and large firms in Indonesian manufacturing. The first research question is whether there is gap between small and large firms, and if so whether it is increasing or decreasing with and without controlling for firm characteristics such as age, finance and export orientation as well as, industry and macroeconomic environment. The second questions is having to do with the globalization itself, whether the opening of domestic market through trade and FDI liberalization affect firms disproportionately according to their size. In particular, whether small firms are more of recipients of negative impacts in terms of declining sales, profitability while the potential gains from globalization such as international networking and access to market information is mostly out of reach. Besides firm from different sizes, the distinction between firms is also based on certain types of facilities (range from tax incentives to custom and location facilities) due to investment sizes versus to those without facilities. Two indicators based on growth and productivity will be constructed to measure the performance gap between different sizes.

\section{Literature Review}

Firms will operate optimally if their environments are supportive. Although some risks can be anticipated, firms will not operate if uncertainties are too large. While it is agreed that the primary functions of government include maintaining law and order, providing basic infrastructures, and regulation of firms and transactions to address information asymmetries, externalities and market power, there also other government policies and behavior that play critical role in affecting the costs, risks, and barrier to competition faced by firms. They include approaches to regulation and taxation, the functioning to of markets for finance and labor, and broad aspect of governance including corruption.

Firms assess investment opportunities and related government policies and behavior as a package, not in a partial fashion. Firms' investment decisions reflect their expectation about future. Not just current conditions. That makes it essential 
for government to foster credibility and stability. Finally firms will operate optimally if their environments are supportive. While it is agreed that the primary functions of government include maintaining law and order, providing basic infrastructures, and regulation of firms and transactions to address information asymmetries, externalities and market power, there also other government policies and behavior that play critical role in affecting the costs, risks, and barrier to competition faced by firms. They include approaches to regulation and taxation, the functioning to of markets for finance and labor, and broad aspect of governance including corruption.

Perhaps, the most crucial regulations pertaining to private firms have been laws governing investment in Indonesia which are designed to minimize uncertainties. The investment law in Indonesia started in 1967 by the introduction of Law number 1 on foreign direct investment to be followed later in 1968 by Law number 6 on domestic investment. Facilities given to investors may include net income tax deduction up to certain level of investment within predetermined period, import duty holiday or reduction for imported capital goods imports, machinery or equipment unavailable domestically, import duty holiday and reduction for imported raw and supporting materials for production unavailable domestically for certain period and certain conditions, accelerated depreciation or amortization and property tax reduction for certain businesses in certain regions.

\subsection{Trade Policy and Other Regulatory Reforms mid 1980s}

The pivotal moment came in 1986 when as a response of the fall of oil price which was then the main source of Indonesian export and government revenues, the government started to deregulate the economy. Indonesia adopted a series of measures that had the effect of significantly liberalizing trade. In January 1982, a package of policies was introduced to simplify export/import approval procedures, giving exporters greater freedom in the use of their export proceeds, providing subsidized export credit, and strengthening the obligations of foreign holders of government contracts to arrange export to the equivalent value of imported material used (Kuncoro, 2018).

Tariffs were reduced across the board and the number of tariff categories was cut in March 1985. In May 1986, those industries producing for export were allowed to purchase imported inputs without restriction and without import duties. In October 1986, the import licensing system was revamped and import restrictions were lifted from a wide range of products. Other major regulatory reforms were related to investments. In April 1985, approval procedures for foreign investments were simplified. In 1986, a package of reforms was introduced to provide foreign companies with the same privileges as domestic companies in securing local credit, flexibility in reinvesting profits and the right to distribute products directly rather than going through an Indonesian intermediary. The reforms also reduced foreign equity requirements, and relaxed the requirements for divesture. 


\subsection{Economic Reforms during 1991-1997}

In 1991, there was no looming crisis of the magnitude seen in the 1960s and 1980s, but concern for the apparent slowing down of non-oil exports became the focus of many policy makers. The government indicated its concern in April 1994 and started to establish an inter-Ministry team headed by the Coordinating Minister for Industry and Trade to study the cause of the decline (Pangestu and Azis, 1994). It was believed one reason behind the economic slowdown was the slackening of the pace of deregulation. One indication was that the nominal tariff that showed a decreasing trend in the previous period hardly changed at all during the 1991-94 period.

In 1994, in response to this situation, the government announced a bold economic deregulation, mainly related to investment and trade policies, which included the abolition of the limitation on foreign ownership, a reduction of the trade barrier in the form of tariff cuts, and the opening up of 10 previously closed sectors to foreign investment (Pangestu and Azis, 1994). The divestment rule, which had been major deterrent to foreign investors, was abolished. Under the new rule, foreign investors were allowed to form either a joint venture with 95 percent majority equity ownership without any further divestment obligation or to have full ownership (100 percent stake) of a business entity in Indonesia. In addition, firms 100 percent owned by foreigners were also allowed to invest in all areas in Indonesia.

Another trade reform, called the May package, was introduced in 1995. The package encompassed a significant and almost across the board reduction in tariffs, as well as a pre-announced schedule of further tariff reductions to the year 2003. Further, more transparent tariff surcharge was enacted to replace the remaining non-tariff barrier (NTB). The best part of the May package was the components that improved trade, investment and business facilities. A simpler industrial permit replaced the permanent business permit. It also modified customs procedures by waiving pre-shipment inspection of imported goods transported by air. These could now be cleared through normal custom procedures at the airports. It also waived custom inspection of exports goods moved between bonded zones and entry ports.

\subsection{Post Asian Crises}

The Asian economic crises in 1998 slowed down the economic growth considerably. The economic and investment growth remained subdued. It took almost 5 years for the economy to recuperate. The reason behind the slowdown can be tracked to the worsening investment climate due the chaotic days of the Abdurrahman Wahid Presidency, his eventual impeachment and the ascension of Vice President Megawati to the presidency. This political development had big impact on the market confidence (Siregar, 2001). The launching of decentralization law in 2001 also created huge uncertainty on the part the business sector (Kuncoro, 2004). 
The severe global recessions in 2008-09 once again put a brake on the economy. There has been no big bang policy on economic deregulation as pivotal as in mid 1980s. In 2007 the new investment law is launched with the purpose of combining domestic and foreign investment laws but there has been no major policy change. In terms of economic policy, Indonesia has continued to rely on a combination of deregulation, market liberalization and a series of fiscal incentives to lure investors both foreign and domestic.

To boost overall growth, there has been a renewal interest to boost the performance of small firms. There have been numerous policy interventions to improve the performance of small firms. The latest is the KUR (Kredit Usaha Rakyat) program which has been in place since 2007 till today. Some of manufacturing firms the medium ones (less than 100 employees) may have been eligible and exposed to this program.

\section{Method}

Based on the policy context above our research strategy is to use mid 1980s as a dividing line between heavily deregulated versus more open and less deregulated economy to examine whether given their size or status, it would have any impacts on manufacturing firms' behavior. ${ }^{1}$ This exercise is repeated to compare the 1986-90 where the reforms are mostly trade related and 1991-96 periods where the reforms mainly investment and input importation to examine the behavior changes between those two periods. Due to the realibility of firm identifier, only the samples of the 1991-96 and after the Asian financial crisis (AFC) (2000-2008) from the BPS annual manufacturing will analyzed.

\subsection{Data}

The main data sets used in this study is the series of annual manufacturing survey from 1981 to 2008. It covers all industries in the large and medium manufacturing and the series are long. Potentially, we can construct a long panel data to study the dynamic of firm performances for all indicators mentioned above.

\subsection{Performance Gap between Small and Large Firms}

Although the term of firm performance is well understood, translating it into more 'operational' variables for empirical exercise is another matter. The conventional way to measure it is to use productivity and wages. To examine the general trend of gaps between small and large firms, the indicator in question will be measured at the firm level.

\footnotetext{
${ }^{1}$ In the post-2000 years there are no obvious dividing line to separate the period into two distinct regimes.
} 
Defining small versus large is also problematic. The census on small firm is only conducted every 10 years by BPS (Central Statistical Agency) so examining a long-run trend in a year to year basis is out of question. Alternatively, one can use the portion of medium and large manufacturing survey from BPS which can be considered as small and medium let say a firm size below 100 workers.

Globalization can be considered as a regime change from relatively highly regulated and protected economy to more open and deregulated one. One can think about as a simple evaluation policy where a number of different industries present before the policy is enacted and on the same industries after it is enacted. Any economic reform that involves trade and/or investment liberalization will suit into this definition.

Let us define $S$ (small) a dummy variable if a firm total number of workers do not exceed 100, M (medium) a dummy variable for a firm with workers above 100 and 500, and L (larger) for those with workers above 500.We examine whether the opening of domestic market in 1986 affected firms disproportionately according to their size. In particular, the question is whether small firms are more of prone to negative impacts such as of declining sales, and profitability. For this purpose we use performance indicators discussed above. To put this into a regression model

$$
Y_{i t}=\beta_{0}+\alpha_{1} \cdot S_{i t}+\alpha_{2} \cdot L_{i t}+\delta . t+\gamma \cdot g_{i}+X_{i t} \Gamma+\varepsilon_{t}
$$

In equation (1) $Y_{i t}$ is the dependent variable measuring the firm level performance discussed above for each firm small or large. The variable $S_{i t}$ is defined as equal to one if it is a small firm and the year is from 1986 onward or else equal to zero, $L_{i t}$ will have the value of one if it is large firms and the time is after 1985 or from 1986 onward or equal to zero otherwise. The variable $g_{i}$ captures firms' fixed effects. Lastly vector $X$ captures all other covariates. In the second set regression the cutting off for the time dummy is the year of 1990s as the dividing line between first phase (mainly trade) and the second phase (mainly investment) of economic liberalization. Finally before and after AFC periods are compared using 2000 as the cut-off year.

Following Kokko (1994) and Takii (2005) they are defined as the average wage gap, and the average labor productivity. While productivity is a straightforward measurement of technological gap, wage gap is worth of explanation. If the wage gap between small and large firms is indeed large and getting larger, it would be difficult for small firms to lure workers to leave large firms because they could not offer a large wage premium. As a result there would be very little knowledge spillover from large to small firms through employment turnover. Small firms would remain lag behind unable to reap the benefits of globalization. 


\section{Result}

\subsection{Firm Dynamic}

Table 1 and 2 present the composition of the manufacturing sector in Indonesia. Small firms are the most numerous entities of about 70 to 77 percent of total manufacturing firms. Medium firms come in second of 16 to 21 percent of total stock of firms. Finally, large firms contribute to 5 to 9 percent of total firms. These positions are reversed when value added creation is considered. Large firms are the biggest contributor, with the share between 61 to 73 percent, to be followed by medium category ( 23 to 31 percent) and small firms (6 to 12 percent). In later years the contribution of larger firms are declining to as low as 61 percent as small and medium size are increasing their portions. Still, due to its commanding share, any slowdown or improvement of manufacturing growth observed after 2000 is partly attributable to the performance of large firms (Table 2).

Table 1: Firm Composition in Indonesian Manufacturing by Size

\begin{tabular}{ccccc}
\hline Year & \% small & \% medium & \% large & Total Firms \\
\hline 1981 & 77.8 & 16.8 & 5.5 & 7,942 \\
1985 & 77.9 & 16.8 & 5.4 & 12,909 \\
1988 & 75.5 & 18.8 & 5.7 & 14,664 \\
1996 & 71.3 & 20.9 & 7.8 & 22,968 \\
2000 & 69.7 & 21.9 & 8.5 & 22,174 \\
2008 & 73.7 & 19.3 & 7.0 & 25,684 \\
\hline Source: Calculated from Manufacturing Surveys, various years
\end{tabular}

The drop of small firm presence in 2000 suggests that the AFC in 1998-1999 had hit them hard but things started to improve afterward. In 2008 the increase of the share of small firms and the decrease of both medium and large size in manufacturing reflects the situation where the net entry is once again dominated by small firms as in 1981 and 1985.

The entry of new firms is a good thing in the sense that it may bring new technology and knowledge to the industry. The process is however is not easy particularly for small firms. Small firms need to overcome many obstacles related to market information, financial access and accumulated. Information on productivity, wage, profitability and output gaps may provide hints how well small firms can adapt and survive in the industry.

In Figure 1 using medium size firms as a point of reference labor productivity gap between small and large firms are plotted for the periods of 1981 to 2008. The overall pattern suggest that while the gap between large and medium size are almost unchanged overtime. Small firms are able to catch up with large ones at least to narrow the gaps but afterward the gap persists. ${ }^{2}$ Interestingly, the

\footnotetext{
${ }^{2}$ The gap between medium and large size is almost unchanged overtime suggesting a "middle size trap" when a firm attempts to graduate to large size.
} 
Table 2: Manufacturing Value Added Composition by Size (\%)

\begin{tabular}{cccc}
\hline Year & Small & Medium & Large \\
\hline 1981 & 7.0 & 23.8 & 69.2 \\
1985 & 12.4 & 30.9 & 56.6 \\
1988 & 9.3 & 28.5 & 62.2 \\
1996 & 6.7 & 20.6 & 72.7 \\
2000 & 7.5 & 24.6 & 67.9 \\
2008 & 7.2 & 313 & 61.5 \\
\hline Source: Calculated from Manufacturing \\
\multicolumn{3}{c}{ Surveys, various years }
\end{tabular}

introduction of economic reforms and market liberalization tends to widen the gap but the gaps then become smaller again though before going back to its long-run pattern.

One interesting illustration of this process is that the introduction of economic reforms and market liberalization in mid 1980s widened the gap (Figure 1). Large firms were in better position to cope with new found opportunities in more open and less regulated economy brought by the reforms. Overtime in 1996 however the gap was once again declining. Small firms were still in the process of narrowing the gap to large enterprises when the AFC struck in 1998. The AFC itself had made the gap to be larger again suggesting that small firms hap hard time to cope with the crisis but gradually coming back to a level before the crisis. At this point we have not determined precisely the avenue through which small firms narrowed the gaps but there were many alternatives: value-chain, agglomeration effects, labor market and/or general market information.

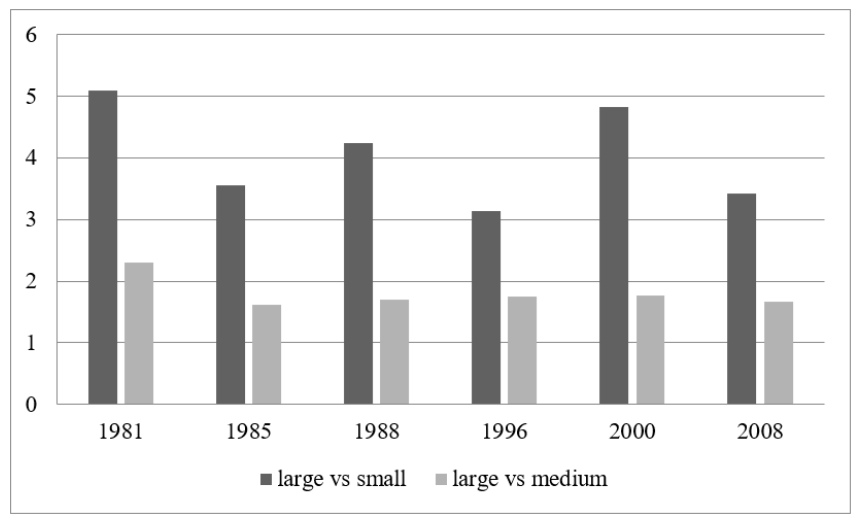

Figure 1: Labor Productivity Gap in Indonesian Manufacturing

Source: Calculated from Manufacturing Surveys, various years 


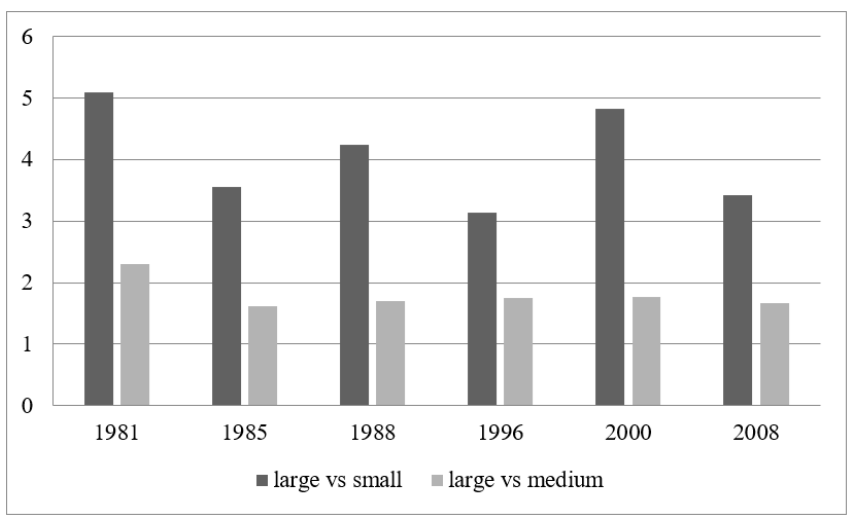

Figure 2: Wage Gap by Firm Size

Source: Calculated from Manufacturing Surveys, various years

We performed an exercise to examine whether labor market serves small firms as a potential channel for catching-up. In Figure 2 we plot the wage gap between small and large firms. Large firms pay workers about twice as much as small ones. There is a little evidence that small firms can match large ones' wage offers. It would be difficult for small enterprises to attract workers from large firms to move. In the labor market it may have difficulty to lure talented new entrants. So labor market is the less likely avenue of which small firms try to catch-up with large ones in terms of productivity.

The presence of FDI can be used to signify the extent of globalization at the firm, industry and national levels. Potentially FDI firms can function as sources of knowledge spillover as well as 'sparring partner' for domestic firms to increase their competitiveness. As the economy is opening up we expect domestic firms to learn their lesson in order to catch-up. In Figure 3, we examine labor productivity gap between FDI and non FDI firms.

Before mid-1980s the productivity gap between FDI and non FDI had been declining. In the aftermath of the mid 1980s economic reform the gap was widening again owing to the influx of new FDI firms which continue until 2000 when the gap is at the largest. At the same time the existing FDI firms also used this opportunity to improve its production technology by importing new machinery. This combination has resulted in the situation where at its peak the productivity in FDI firms is seven times as high compared to their non FDI counterparts.

The AFC caused many non FDI firms to go out of business or changing hand. This turns out to be blessing in disguise as many bankrupt firms after 2000 have new owners and ready to enter market with new technology. As a result the labor productivity ratio between FDI and non FDI firms fell to 4, the lowest in 30 years. The wage gap while it has been large, it has never been excessive (Figure 4). Since 1988 the trend has been falling. In 2008 the ratio between FDI and non-FDI wages 


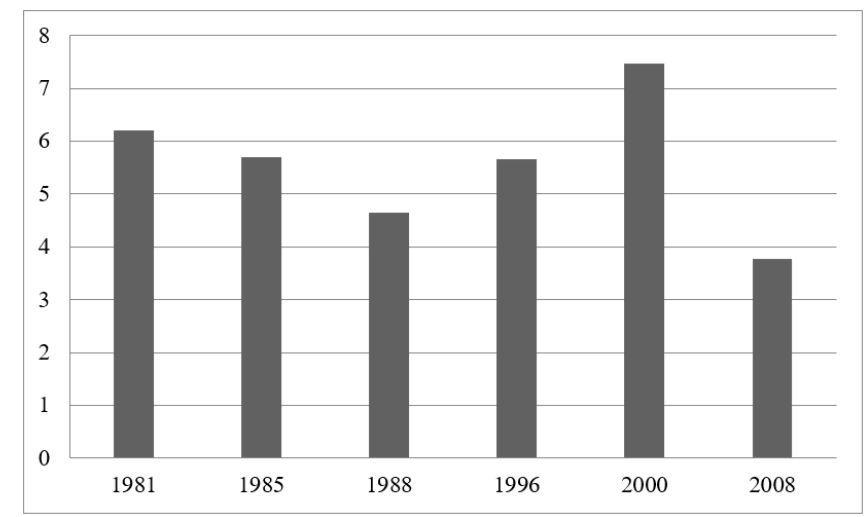

Figure 3: Labor Productivity Gap - FDI versus non-FDI

Source: Calculated from Manufacturing Surveys, various years

stood at slightly below 2 . This gap however is not small enough to persuade workers from FDI sector to non-FDI, unless in the case of forced lay-off. Therefore the spillover between FDI and non FDI could not depend on labor turnover.

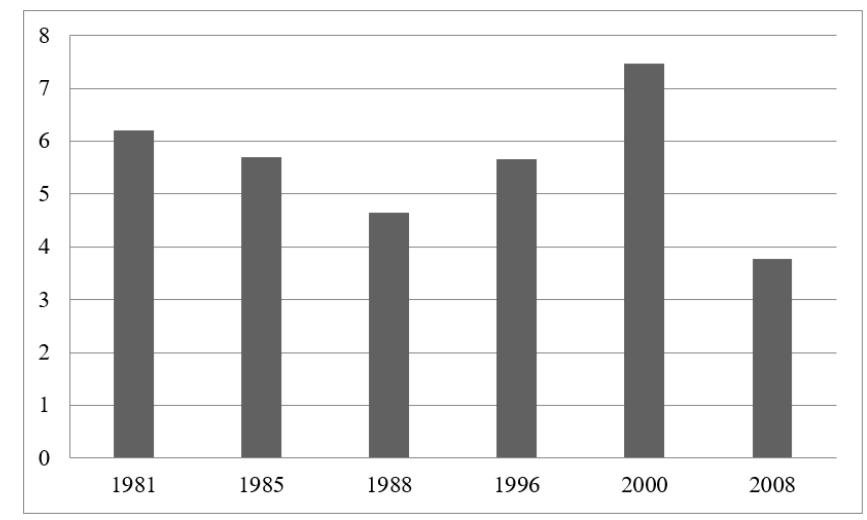

Figure 4: Wage Gap - FDI versus non-FDI

Source: Calculated from Manufacturing Surveys, various years

\subsection{Empirical Results}

The model of equation (1) is estimated for three periods under consideration above; 1981-90 with the year of 1985 as the dividing line between pre-reform (1981-1985) and first-period reform (1986-1990), 1986-1996 with the year of 1990 as the cut-off between the period of "trade" reform and "ownership-input and 
capital importation" and lastly before and after AFC. Capital intensity (ratio of capital to labor) is used to control for the initial size of firm. Besides investigating the growth of various indicators between small and large firms using the medium size we also consider other variables that may affect growth such as agglomeration, input importation, access to external loans, effective rate of protection (tariff) and export orientation.

\subsubsection{Wage Growth}

In Table 4 the basic regressions of wage growth are estimated for three different time periods. The size dummies indicate that the wages for large firms in 1981-85 and 1990-96 wages grow faster than small firms. After 1985 there is no sign that small firms are catching up, the time and size interaction is not significant for all size category. The results suggest that the labor market is not used by small firms to learn from large ones as they constitute different segment of market and very difficult for small firms to lure workers from large companies. Comparing before and after AFC in the subsequent period, large firms grow faster than small ones as the interaction between large and time is weakly significant at 10 percent level, so the gap will persist into the future.

In Table 4 we also investigate whether agglomeration of industries is the way for small firms to close their gaps with large firms. Centralization of industrial location at least in the early stages may bring benefits to firms. One important benefit of agglomeration is that firms conducting R\&D can learn from each other, to create a synergy that collectively boosts their average performances.

Agglomeration externality is meant to capture interaction among firms within a district. It is measured by a diversity index. For district i for example, the index of diversity is

$$
g_{i}^{s}=\sum_{j=1}^{J}\left[\frac{E_{i j}(t)}{E_{i}(t)}-\frac{E_{j}(t)}{E(t)}\right]^{2}
$$

$E(t)$ is total national manufacturing employment and $E_{j}(t)$ is total national employment in industry $j$. Meanwhile, $E_{i}$ and $E_{i j}$ are the corresponding local magnitudes. The measure of urbanization economies $g_{i}^{s}(t)$ has a minimum value of zero, where in a district, each industry's share of local manufacturing employment is exactly the same as its national share, so the district is completely unspecialized because its industrial composition is merely a copy of the nation. At the other end, the maximum value of $g_{i}^{s}(t)$ will approach two for a district completely specialized in one industry, while at the same time national employment is concentrated in another industry. The higher is $g_{i}^{s}(t)$ the lower is the diversity, thus a district becomes more specialized.

The results suggest that with respect to wage growth, small and large firms do not enjoy benefits from industrial agglomeration. After AFC, wage for large firms grows slower relative to medium and small firms. The coefficient of interaction between time and large size is negative and significant at 10 percent level. This is 
a good sign for narrowing gap but tt is not certain however whether small firms can attract workers from large firms since the initial gap may have been large to begin with.

The agglomeration of FDI in vicinity has no impact on small and large firms (Table 4). None of the interaction between size, agglomeration and time dummy variables is significant. There is no differential effect between before and after reform or before and after AFC. It brings negative impact for wage growth of smaller firms after AFC. Overall, the positive impact of FDI on wage growth is only observed in the 1986-90 to 1990-1996 samples. The impact becomes negative after AFC. It is hard for domestic firms to keep pace with FDI when it comes to pay wages especially after AFC.

We also examine the impact of external financing in the form of loans. Fazzari et al. (1988) and Hubbard (1998) provided the theoretical and empirical framework underpinning of the relationship between cost/access of borrowing and investment. In this setting, a firm is considered as financially constrained if the cost or availability of external funds prevents a firm to exercise the level of the optimum investment $I_{i t}^{*}$ (Bhaduri, 2005) which eventually affect firm performances. In general, the access to external loans has no impact on wage growth (Table 4).

One way for a government to shield certain sectors from global competition is through tariff protection. This barrier will alter industry's relative profitability by creating an artificial price wedge. How the protection will affect firms of different size is at best ambiguous. If the market is contestable then the extra profit can reinvested in R\&D to boost firms' competitiveness in anticipation for the day when the protection is eventually lifted. In Table 4 we examine the impact of tariff in the form of effective rate of protection (ERP).

If large firms have cost advantages to carry out R\&D over small companies then performances may deviate by size. On the other hand, high artificial profits could also make less pressure for firms to do R\&D so the differences between large and small firms may not be apparent. To measure ERP we use the concept of effective rate of protection (ERP) as in Amiti and Konings (2005).

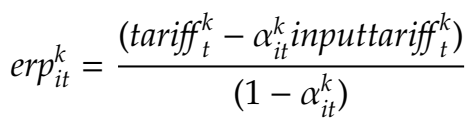

Where $\alpha_{i t}^{k}$ is the ratio of input to output for firm $i$ in industry $k$ at time $t$. A lower output tariff would decrease the protection enjoyed by industry $k$, while a lower input tariff would increase the protection received by industry $k$.

The impact of ERP is negative for wage growth especially for large firms in the 1986-90 to 1991-96 samples. In later half of the 1986-90 to 1991-96 periods the impact for small firms is also negative.

The ability to secure vital inputs is very important if a firm want compete globally. If such inputs are not available domestically then trade regime should be reasonably open for importation. The 1990 reform had made it easier to import inputs from abroad. The positive impact is enjoyed by large firms especially it 
moves from pre-reform to the early phase of reform era (the 1981-85 to 1986-90 samples) as well as from the first phase (1986-90) to the second phase of reforms (1991-96). The interaction between time, large size and foreign input is positive and significant at 5 percent level. The positive impact however dissipates after AFC (Table 3). So the overall impact with respect to foreign input importation increases the gap between small and large firms in the ability to attract the best workers into their establishments.

As a result of the dismantling trade barrier, a firm has options to go to export markets. For this they need to be more innovative and more efficient. There is two way relationships. First, export marker would discipline firms in order to compete. In the reversed direction, only those with sufficient level of innovation and cost efficient are able to enter export market. Export orientation and economic reforms are expected to show up in firms' good performance indicators. In general, for all size categories being exporter has no impact on wage growth. Also for all firms wage growth slows down after AFC (Table 3).

\subsubsection{Labor Productivity Growth}

All exercises above are repeated for labor productivity growth. The results are are presented in Table 4 . In terms of labor productivity there is no sign that the growth is different between small and large firms. None of the interacted time and firm size is positive and significant. The only significant coefficient is for large firms. The growth of large firms is slower when it moves from the pre-reform era (1981-85) to the first reform era (1986-90).

Effective rate of protection in general has positive effect for large firms but negative for small firms. There is however no differential effect between before and after reforms as well as before and after AFC. Small firms also do not benefit from locating in industrial agglomeration areas in all cases of reforms and in the aftermath of AFC. After AFC the productivity growth of large firms in the agglomeration areas is slower compared to other size types.

Not everything is bad for small firms. Related to the issue of agglomeration is the impact of FDI firms in the vicinity as they may be the important source of technological spillover. The impact of the presence of FDI firms in the vicinity is positive for productivity growth in the 1981-85 to 1986-90 samples (from pre to first phase reform. The effect is statistically weaker in the second phase of reforms in the 1986-90 to 1991-96 samples. The same picture also applies to large firms. After further reforms are introduced in the 1991-96 periods, the impact of FDI turns negative for small firms. The interaction between time and small size is negative and significant while that of large firms is not significant. This suggests that eventually the productivity growth of small and large firms starts to diverge after almost all measures in the reform sequence have been introduced.

Excessive dependence on imported inputs seems to impact productivity growth negatively for both small and large firms if the pre-reform era. The negative effects however disappear after reforms are introduced or broadened. The interaction between imported input and time is mostly insignificant in the 
1981-85 to 1986-90 and the 1986-90 and 1991-96 samples. This variable turns into positive and significant in the post AFC period as input importation become easier. Being exporter is good for small firms in the sense that the productivity growth is higher compared to medium and large. In the post AFC however, productivity growth of small firm exporter is significantly lower than large firms suggesting the divergence path.

\section{Conclusion}

This paper examines the impact of globalization in the form of two successive economic reforms from 1986 to 1994 on the performance gap between small and large firms in Indonesian manufacturing. Our empirical results suggest that opening up the economy through market liberalization would increase the gap between large and small firms for productivity and wages before it is stabilized again.

Overtime if there is no economic shock, small firms may be able to catch-up at least partially, but the gaps, although become narrower, would persist overtime. There are many avenues through which small firms could exploit knowledge spillover but labor turnover may not be the best source. For small firm positive externalities from industrial agglomeration are also minimal. Other factors such as financial access, export orientation have minimal impact on both large and small firms.

One important finding is that small firms however benefits from more open trade regime after AFC which enable them to acquire imported inputs. The policy option is to maintain open access for input importation. Medium and large firms have more chance to benefit from the opening up of the economy. To be able to reap the benefits the complementary factors such as FDI agglomeration are important. In this case however the benefits for small sized firms for all size are limited given their limitation to carry out R\&D. The presence of FDI creates spillover for small firms at least at the early phase of economic reforms easing the necessity to do costly adaptation for both market and technological information. The spillover may not come from labor turnover as the wage gap continues to persist.Nevertheless, small firms located close to FDI sites may have supplierbuyer relationship and workers in their spare time may exchange information on how the businesses are done.

\section{References}

[1] Agarwal, R., \& Audretsch, D. B. (2001). Does entry size matter? The impact of the life cycle and technology on firm survival. The Journal of Industrial Economics, 49(1), 21-43. doi: https://doi.org/10.1111/1467-6451.00136.

[2] Amiti, M., \& Konings, J. (2005). Trade liberalization, intermediate inputs, and productivity: Evidence from Indonesia. IMF Working Paper No. 05/146. International Monetary Fund. https://www.imf.org/en/Publications/WP/Issues/2016/12/31/ 
Trade-Liberalization-Intermediate-Inputs-and-Productivity-Evidence-fromIndonesia-18377.

[3] Bertschek, I. (1995). Product and process innovation as a response to increasing imports and foreign direct investment. The Journal of Industrial Economics, 43(4), 341-357. doi: 10.2307/2950548.

[4] Bhaduri, S. N. (2005). Investment, financial constraints and financial liberalization: Some stylized facts from a developing economy, India. Journal of Asian Economics, 16(4), 704-718. doi: https://doi.org/10.1016/j.asieco.2005.06.001.

[5] Braga, H., \& Willmore, L. (1991). Technological imports and technological effort: an analysis of their determinants in Brazilian firms. The Journal of Industrial Economics, 39(4), 421-432. doi: 10.2307/2098441.

[6] Caves, R. E., \& Porter, M. E. (1977). From entry barriers to mobility barriers: Conjectural decisions and contrived deterrence to new competition. The Quarterly Journal of Economics, 91(2), 241-261. doi: 10.2307/1885416.

[7] Evans, D. S. (1987). The relationship between firm growth, size, and age: Estimates for 100 manufacturing industries. The Journal of Industrial Economics, 35(4), 567-581. doi: $10.2307 / 2098588$.

[8] Fazzari, S. M., Hubbard, G. R., \& Petersen, B. C. (1988). Financing Constraints and Corporate Investment. Brookings Papers on Economic Activity, I, pp. 141-208. doi: 10.2307/2534426. https:/ / www.brookings.edu/wp-content/uploads/1988/01/ 1988a_bpea_fazzari_hubbard_petersen_blinder_poterba.pdf.

[9] Harris, J. R., Schiantarelli, F., \& Siregar, M. G. (1994). The effect of financial liberalization on the capital structure and investment decisions of Indonesian manufacturing establishments. The World Bank Economic Review, 8(1), 17-47. doi: https://doi.org/10.1093/wber/8.1.17.

[10] Hubbard, R. (1998). Capital-market imperfections and investment. Journal of Economic Literature, 36(1), 193-225.

[11] Kokko, A. (1994). Technology, market characteristics, and spillovers. Journal of Development Economics, 43(2), 279-293. doi: https:/ / doi.org/10.1016/0304-3878(94)900086.

[12] Kuncoro, A. (2004). Bribery in Indonesia: some evidence from microlevel data. Bulletin of Indonesian Economic Studies, 40(3), 329-354. doi: https://doi.org/10.1080/0007491042000231511.

[13] Kuncoro, A. (2006). Decentralization and corruption in Indonesia: Manufacturing firms survival under decentralization. Working Paper Series Vol. 2006-25. The International Centre for the Study of East Asian Development.

[14] Kuncoro, A. (2018). Trends in the Manufacturing Sector under the Jokowi Presidency: Legacies of Past Administrations. Journal of Southeast Asian Economies, 35(3), 402-424.

[15] Pangestu, M., \& Azis, I. J. (1994). Survey of recent developments. Bulletin of Indonesian Economic Studies, 30(2), 3-47. doi: https://doi.org/10.1080/00074919412331336587.

[16] Porter, M. E. (1979). The structure within industries and companies' performance. Review of Economics and Statistics, 61(2), 214-227. doi: 10.2307/1924589.

[17] Siregar, R. Y. (2001). Survey of recent developments. Bulletin of Indonesian Economic Studies, 37(3), 277-303. doi: https:/ /doi.org/10.1080/00074910152669127.

[18] Takii, S. (2005). Productivity spillovers and characteristics of foreign multinational plants in Indonesian manufacturing 1990-1995. Journal of Development Economics, 76(2), 521-542. doi: https:/ /doi.org/10.1016/j.jdeveco.2004.01.006. 


\section{Appendix: Regression Table}

Table 3: Determinant of Wage Growth

\begin{tabular}{|c|c|c|c|}
\hline \multirow{3}{*}{ VARIABLES } & \multicolumn{3}{|c|}{ Wage Growth } \\
\hline & $1981-85$ to $1986-90$ & $1986-90$ to $1991-96$ & $1991-96$ to $2000-08$ \\
\hline & Year $=1$ after 1985 & Year=1 after 1990 & Year=1 after 2000 \\
\hline \multirow[t]{2}{*}{ Year dummy } & $-0.0767^{* * *}$ & $0.0529^{* * *}$ & $0.106^{* * *}$ \\
\hline & $(-4.050)$ & $(2.854)$ & $(11.32)$ \\
\hline \multirow[t]{2}{*}{ Small firms } & -0.0356 & 0.013 & -0.0089 \\
\hline & $(-1.615)$ & $(0.835)$ & $(-1.098)$ \\
\hline \multirow[t]{2}{*}{ Large firms } & $0.0593^{*}$ & 0.0118 & -0.0236 \\
\hline & $(1.667)$ & $(0.399)$ & $(-0.967)$ \\
\hline \multirow[t]{2}{*}{ Small X Year } & 0.0327 & -0.0191 & 0.00185 \\
\hline & $(1.486)$ & $(-0.851)$ & $(0.174)$ \\
\hline \multirow[t]{2}{*}{ LargeX Year } & -0.0581 & -0.0239 & $0.0494^{*}$ \\
\hline & $(-1.645)$ & $(-0.447)$ & $(1.823)$ \\
\hline \multirow[t]{2}{*}{ ERP } & & $-0.00852^{* * *}$ & 0.000525 \\
\hline & & $(-3.368)$ & $(0.565)$ \\
\hline \multirow[t]{2}{*}{ ERP X Year } & & $0.0411^{*}$ & 0.00314 \\
\hline & & $(1.675)$ & $(0.520)$ \\
\hline \multirow[t]{2}{*}{ Small X ERP } & & 0.0145 & 0.00347 \\
\hline & & $(0.959)$ & $(0.728)$ \\
\hline \multirow[t]{2}{*}{ Large X ERP } & & $-0.0939^{* *}$ & -0.00658 \\
\hline & & $(-2.118)$ & $(-0.272)$ \\
\hline \multirow{2}{*}{ Small $X$ ERP $X$ year } & & $-0.0538^{*}$ & 0.0113 \\
\hline & & $(-1.776)$ & $(0.821)$ \\
\hline \multirow[t]{2}{*}{ Large $X$ ERP X year } & & 0.0465 & 0.0239 \\
\hline & & $(0.811)$ & $(0.847)$ \\
\hline \multirow[t]{2}{*}{ Agglomeration (yes) } & 0.00951 & 0.00591 & $0.0143^{* *}$ \\
\hline & $(0.628)$ & $(0.501)$ & $(2.298)$ \\
\hline \multirow[t]{2}{*}{ Agglo. X Year } & -0.00956 & -0.00361 & $-0.0315^{* * *}$ \\
\hline & $(-0.630)$ & $(-0.233)$ & $(-3.847)$ \\
\hline \multirow[t]{2}{*}{ Small $\mathrm{X}$ agglo } & -0.00108 & 0.00367 & -0.00336 \\
\hline & $(-0.0592)$ & $(0.268)$ & $(-0.474)$ \\
\hline \multirow[t]{2}{*}{ Large $\mathrm{X}$ agglo } & 0.0147 & 0.0212 & $0.0286^{* *}$ \\
\hline & $(0.512)$ & $(1.068)$ & $(2.055)$ \\
\hline \multirow[t]{2}{*}{ Small $X$ agglo $X$ year } & 0.000325 & 0.00452 & $0.0329^{* * *}$ \\
\hline & $(0.0178)$ & $(0.241)$ & $(3.506)$ \\
\hline \multirow[t]{2}{*}{ Large $X$ agglo $X$ year } & -0.0153 & 0.017 & $-0.0392^{* *}$ \\
\hline & $(-0.535)$ & $(0.610)$ & $(-2.107)$ \\
\hline \multirow[t]{2}{*}{ Share of FDI value added } & -0.0367 & -0.0633 & $0.0932^{* * *}$ \\
\hline & $(-1.042)$ & $(-1.300)$ & $(3.626)$ \\
\hline \multirow[t]{2}{*}{ Share FDI VA $X$ year } & 0.0338 & $0.160^{* * *}$ & $-0.0601^{* *}$ \\
\hline & $(0.946)$ & $(2.683)$ & $(-1.960)$ \\
\hline \multirow[t]{2}{*}{ Small $X$ share FDI VA } & 0.0452 & -0.073 & -0.011 \\
\hline & $(1.031)$ & $(-1.237)$ & $(-0.385)$ \\
\hline \multirow[t]{2}{*}{ Large $X$ share FDI VA } & 0.0502 & 0.125 & 0.0896 \\
\hline & $(0.733)$ & $(1.140)$ & $(1.222)$ \\
\hline \multirow[t]{2}{*}{ Small $X$ FDI share $X$ year } & -0.0292 & 0.0802 & $-0.0563^{*}$ \\
\hline & $(-0.664)$ & $(1.077)$ & $(-1.653)$ \\
\hline
\end{tabular}




\begin{tabular}{|c|c|c|c|}
\hline \multirow{3}{*}{ VARIABLES } & \multicolumn{3}{|c|}{ Wage Growth } \\
\hline & $1981-85$ to $1986-90$ & $1986-90$ to $1991-96$ & $1991-96$ to $2000-08$ \\
\hline & Year=1 after 1985 & Year=1 after 1990 & Year=1 after 2000 \\
\hline \multirow[t]{2}{*}{ Large X FDI share $X$ year } & -0.0575 & -0.0136 & -0.125 \\
\hline & $(-0.831)$ & $(-0.0867)$ & $(-1.531)$ \\
\hline \multirow[t]{2}{*}{ Imported input } & $0.0653^{* * *}$ & 0.0224 & -0.00214 \\
\hline & (3.029) & (1.383) & $(-0.226)$ \\
\hline \multirow[t]{2}{*}{ Imported input $X$ year } & $-0.0705^{* * *}$ & -0.0225 & 0.00747 \\
\hline & $(-3.253)$ & $(-1.390)$ & $(0.572)$ \\
\hline \multirow{2}{*}{ Small X imported input } & -0.0261 & 0.00526 & -0.00447 \\
\hline & $(-0.994)$ & $(0.280)$ & $(-0.358)$ \\
\hline \multirow[t]{2}{*}{ Large $\mathrm{X}$ imported input } & $-0.114^{* * *}$ & $-0.0737^{* * *}$ & 0.0103 \\
\hline & $(-2.936)$ & $(-2.590)$ & $(0.392)$ \\
\hline \multirow[t]{2}{*}{ Small $X$ imp. input $X$ year } & 0.0216 & -0.00966 & 0.000959 \\
\hline & -0.823 & $(-0.509)$ & $(0.056)$ \\
\hline \multirow[t]{2}{*}{ Large $X$ imp. input $X$ year } & $0.121^{* * *}$ & $0.0715^{* *}$ & -0.0164 \\
\hline & (3.102) & $(2.512)$ & $(-0.547)$ \\
\hline \multirow[t]{2}{*}{ Exporter (yes) } & & 0.00715 & 0.00733 \\
\hline & & $(0.469)$ & (1.108) \\
\hline \multirow[t]{2}{*}{ Exporter $\mathrm{X}$ year } & & 0.016 & $-0.0193^{* *}$ \\
\hline & & $(0.864)$ & $(-2.313)$ \\
\hline \multirow{2}{*}{ Small $\mathrm{X}$ exporter } & & -0.026 & 0.0102 \\
\hline & & $(-1.196)$ & $(1.025)$ \\
\hline \multirow[t]{2}{*}{ Large $\mathrm{X}$ exporter } & & -0.00742 & -0.00837 \\
\hline & & $(-0.331)$ & $(-0.594)$ \\
\hline \multirow[t]{2}{*}{ Small $\mathrm{X}$ exporter $\mathrm{X}$ year } & & 0.0437 & -0.00932 \\
\hline & & (1.484) & $(-0.758)$ \\
\hline \multirow[t]{2}{*}{ Large $X$ exporter $X$ year } & & -0.013 & 0.0185 \\
\hline & & $(-0.413)$ & (1.063) \\
\hline \multirow{2}{*}{ External loan (yes) } & -0.00908 & 0.00593 & -0.00498 \\
\hline & $(-0.627)$ & $(0.534)$ & $(-0.715)$ \\
\hline \multirow{2}{*}{ Loan $\mathrm{X}$ year } & 0.00854 & -0.0151 & 0.0016 \\
\hline & $(0.590)$ & $(-0.965)$ & $(0.178)$ \\
\hline \multirow{2}{*}{ Small X loan } & -0.00342 & 0.00824 & 0.000724 \\
\hline & $(-0.171)$ & $(0.589)$ & $(0.0873)$ \\
\hline \multirow[t]{2}{*}{ Large $\mathrm{X}$ loan } & -0.0211 & -0.0187 & 0.0169 \\
\hline & $(-0.806)$ & $(-0.965)$ & (1.027) \\
\hline \multirow[t]{2}{*}{ Small $X$ loan $X$ year } & 0.00442 & -0.0102 & 0.00904 \\
\hline & $(0.221)$ & $(-0.489)$ & $(0.831)$ \\
\hline \multirow[t]{2}{*}{ Large $X$ loan $X$ year } & 0.0211 & 0.0419 & -0.02 \\
\hline & $(0.803)$ & $(1.285)$ & $(-0.977)$ \\
\hline \multirow[t]{2}{*}{ Age } & $-0.000202^{*}$ & -0.000139 & 6.07E-05 \\
\hline & $(-1.698)$ & $(-0.807)$ & (1.065) \\
\hline Capital Intensity & -0.00182 & 0.0507 & $0.0104^{* * *}$ \\
\hline & $(-0.572)$ & $(1.586)$ & $(4.841)$ \\
\hline Industry dummy & yes & yes & Yes \\
\hline Constant & $0.0831^{* * *}$ & 0.00357 & $0.0868^{* * *}$ \\
\hline & $(4.078)$ & $(0.164)$ & $(7.738)$ \\
\hline Observations & 4,325 & 5,424 & 21,507 \\
\hline R-squared & 0.144 & 0.102 & 0.104 \\
\hline
\end{tabular}

Robust t-statistics in parentheses ${ }^{* * *} \mathrm{p}<0.01,{ }^{* *} \mathrm{p}<0.05,{ }^{*} \mathrm{p}<0.1$ 
Table 4: Determinant of Productivity Growth

\begin{tabular}{|c|c|c|c|}
\hline \multirow{3}{*}{ VARIABLES } & \multicolumn{3}{|c|}{ Labor Productivity Growth } \\
\hline & $1981-85$ to $1986-90$ & $1986-90$ to $1991-96$ & $1991-96$ to $2000-08$ \\
\hline & Year=1 after 1985 & Year $=1$ after 1990 & Year=1 after 2000 \\
\hline \multirow[t]{2}{*}{ Year dummy } & -0.0194 & $-0.174^{*}$ & $0.124^{* * *}$ \\
\hline & $(-0.470)$ & $(-1.701)$ & $(7.371)$ \\
\hline \multirow[t]{2}{*}{ Small firms } & -0.06 & 0.00849 & -0.0121 \\
\hline & $(-1.419)$ & $(0.251)$ & $(-0.737)$ \\
\hline \multirow[t]{2}{*}{ Large firms } & $-0.0864^{*}$ & -0.0247 & -0.0235 \\
\hline & $(-1.747)$ & $(-0.341)$ & $(-0.719)$ \\
\hline \multirow[t]{2}{*}{ Small X Year } & $-3.70 \mathrm{E}-05$ & 0.138 & 0.0087 \\
\hline & $(-0.000725)$ & $(1.296)$ & $(0.427)$ \\
\hline \multirow[t]{2}{*}{ Large X Year } & -0.00989 & 0.137 & 0.0253 \\
\hline & $(-0.144)$ & $(1.013)$ & $(0.670)$ \\
\hline \multirow[t]{2}{*}{ ERP } & & -0.0112 & $0.0299^{* * *}$ \\
\hline & & $(-1.163)$ & $(4.713)$ \\
\hline \multirow[t]{2}{*}{ ERP X Year } & & $0.494^{* *}$ & 0.0179 \\
\hline & & $(2.002)$ & $(0.824)$ \\
\hline \multirow[t]{2}{*}{ Small X ERP } & & $-0.0873^{* *}$ & 0.0234 \\
\hline & & $(-2.441)$ & -0.982 \\
\hline \multirow[t]{2}{*}{ Large X ERP } & & -0.151 & $0.0752^{*}$ \\
\hline & & $(-0.955)$ & $(1.688)$ \\
\hline \multirow[t]{2}{*}{ Small X ERP X year } & & -0.351 & 0.00168 \\
\hline & & $(-1.379)$ & $(0.0459)$ \\
\hline \multirow[t]{2}{*}{ Large $X$ ERP $X$ year } & & -0.262 & -0.0597 \\
\hline & & $(-0.844)$ & $(-0.956)$ \\
\hline \multirow[t]{2}{*}{ Agglomeration (yes) } & -0.0202 & $-0.0512^{* *}$ & 0.0175 \\
\hline & $(-0.480)$ & $(-2.076)$ & $(1.382)$ \\
\hline \multirow[t]{2}{*}{ Agglomeration X Year } & -0.0649 & 0.0573 & -0.023 \\
\hline & $(-1.417)$ & $(1.544)$ & $(-1.449)$ \\
\hline \multirow[t]{2}{*}{ Small $\mathrm{X}$ agglomeration } & -0.078 & 0.0361 & -0.00687 \\
\hline & $(-1.582)$ & $(1.303)$ & $(-0.494)$ \\
\hline \multirow[t]{2}{*}{ Large $X$ agglomeration } & 0.00479 & 0.0392 & 0.014 \\
\hline & $(0.0889)$ & $(0.816)$ & $(0.634)$ \\
\hline \multirow[t]{2}{*}{ Small $X$ agglo. $X$ year } & -0.0175 & -0.0342 & 0.0192 \\
\hline & $(-0.255)$ & $(-0.812)$ & $(1.092)$ \\
\hline \multirow[t]{2}{*}{ Large $X$ agglo. $X$ year } & 0.0176 & -0.0146 & $-0.0522^{*}$ \\
\hline & $(0.666)$ & $(-0.246)$ & $(-1.862)$ \\
\hline \multirow[t]{2}{*}{ Share of FDI value added } & $-0.155^{* *}$ & $-0.203^{* * *}$ & 0.0354 \\
\hline & $(-2.347)$ & $(-2.582)$ & $(0.708)$ \\
\hline \multirow[t]{2}{*}{ Share FDI VA $X$ year } & -0.0267 & $0.385^{* * *}$ & -0.0494 \\
\hline & $(-0.253)$ & $(2.983)$ & $(-0.843)$ \\
\hline \multirow[t]{2}{*}{ Small X share FDI VA } & $0.325^{* * *}$ & $0.184^{*}$ & 0.0692 \\
\hline & $(3.282)$ & $(1.758)$ & $(1.304)$ \\
\hline \multirow[t]{2}{*}{ Large $X$ share FDI VA } & $0.273^{* *}$ & $0.308^{*}$ & 0.0886 \\
\hline & $(2.566)$ & $(1.677)$ & $(0.867)$ \\
\hline Small X FDI share $X$ year & -0.137 & $-0.307^{* *}$ & -0.0881 \\
\hline & $(-0.947)$ & $(-1.967)$ & $(-1.424)$ \\
\hline Large $X$ FDI share $X$ year & 0.0543 & -0.293 & -0.00987 \\
\hline & $(0.257)$ & $(-1.221)$ & $(-0.0845)$ \\
\hline
\end{tabular}




\begin{tabular}{|c|c|c|c|}
\hline \multirow{3}{*}{ VARIABLES } & \multicolumn{3}{|c|}{ Labor Productivity Growth } \\
\hline & $1981-85$ to $1986-90$ & $1986-90$ to $1991-96$ & $1991-96$ to $2000-08$ \\
\hline & Year $=1$ after 1985 & Year $=1$ after 1990 & Year $=1$ after 2000 \\
\hline \multirow[t]{2}{*}{ Imported input } & $0.0892^{*}$ & 0.0436 & $0.0702^{* *}$ \\
\hline & $(1.957)$ & $(1.412)$ & $(2.380)$ \\
\hline \multirow[t]{2}{*}{ Imported input $X$ year } & $-0.119^{* *}$ & -0.0437 & $-0.113^{* * *}$ \\
\hline & $(-2.052)$ & $(-1.415)$ & $(-3.515)$ \\
\hline \multirow[t]{2}{*}{ Small X imported input } & -0.0845 & $-0.0623^{*}$ & $-0.0920^{* * *}$ \\
\hline & $(-1.593)$ & $(-1.766)$ & $(-2.725)$ \\
\hline \multirow[t]{2}{*}{ Large $\mathrm{X}$ imported input } & -0.00893 & 0.0647 & $-0.0947^{* *}$ \\
\hline & $(-0.122)$ & $(0.986)$ & $(-2.343)$ \\
\hline \multirow[t]{2}{*}{ Small $X$ imp. input $X$ year } & 0.0649 & 0.0494 & $0.116^{* * *}$ \\
\hline & $(0.988)$ & (1.393) & $(3.028)$ \\
\hline \multirow[t]{2}{*}{ Large $X$ imp. input $X$ year } & 0.0989 & -0.0671 & 0.059 \\
\hline & -0.979 & $(-1.022)$ & $(1.285)$ \\
\hline \multirow[t]{2}{*}{ Exporter (yes) } & & $-0.0529^{* *}$ & 0.00982 \\
\hline & & $(-2.152)$ & $(0.774)$ \\
\hline \multirow[t]{2}{*}{ Exporter $\mathrm{X}$ year } & & $0.0893^{* *}$ & -0.0146 \\
\hline & & $(2.326)$ & $(-0.957)$ \\
\hline \multirow[t]{2}{*}{ Small $\mathrm{X}$ exporter } & & 0.0252 & $0.0391^{*}$ \\
\hline & & $(0.632)$ & $(1.857)$ \\
\hline \multirow{2}{*}{ Large $\mathrm{X}$ exporter } & & 0.0446 & 0.0165 \\
\hline & & $(0.997)$ & $(0.740)$ \\
\hline \multirow[t]{2}{*}{ Small X exporter $X$ year } & & 0.0537 & $-0.0746^{* * *}$ \\
\hline & & $(0.704)$ & $(-3.116)$ \\
\hline \multirow{2}{*}{ Large $X$ exporter $X$ year } & & -0.0759 & -0.00983 \\
\hline & & $(-1.296)$ & $(-0.367)$ \\
\hline \multirow[t]{2}{*}{ External loan (yes) } & 0.00644 & 0.0365 & -0.00534 \\
\hline & $(0.224)$ & $(1.581)$ & $(-0.333)$ \\
\hline \multirow[t]{2}{*}{ Loan $X$ year } & 0.036 & -0.0494 & 0.00542 \\
\hline & $(0.953)$ & $(-1.276)$ & $(0.288)$ \\
\hline \multirow[t]{2}{*}{ Small $X$ loan } & -0.0249 & -0.0242 & -0.0055 \\
\hline & $(-0.528)$ & $(-0.836)$ & $(-0.315)$ \\
\hline \multirow[t]{2}{*}{ Large X loan } & 0.0114 & $-0.0774^{*}$ & -0.0205 \\
\hline & $(0.245)$ & $(-1.898)$ & $(-0.802)$ \\
\hline \multirow[t]{2}{*}{ Small X loan $X$ year } & 0.00567 & 0.0235 & -0.00945 \\
\hline & $(0.103)$ & $(0.501)$ & $(-0.449)$ \\
\hline \multirow[t]{2}{*}{ Large $X$ loan $X$ year } & -0.0847 & 0.073 & 0.0497 \\
\hline & $(-1.313)$ & (1.297) & $(1.536)$ \\
\hline \multirow[t]{2}{*}{ Age } & $-0.000875^{* * *}$ & -0.000268 & $0.000268^{* * *}$ \\
\hline & $(-2.668)$ & $(-0.808)$ & $(2.842)$ \\
\hline \multirow[t]{2}{*}{ Capital Intensity } & 0.0396 & 0.0783 & 0.0191 \\
\hline & $(0.990)$ & $(0.818)$ & $(1.558)$ \\
\hline \multicolumn{4}{|l|}{ Industry dummy } \\
\hline Constant & $0.109^{* *}$ & 0.0464 & $0.0627^{* * *}$ \\
\hline & $(2.476)$ & (1.138) & $(3.509)$ \\
\hline Observations & 4,321 & 5,429 & 21,517 \\
\hline R-squared & 0.038 & 0.062 & 0.059 \\
\hline
\end{tabular}

Robust t-statistics in parentheses

${ }^{* * *} \mathrm{p}<0.01,{ }^{* *} \mathrm{p}<0.05,{ }^{*} \mathrm{p}<0.1$ 